\title{
Re-oligotrophication of tropical water reservoirs to minimize environmental impact
}

\author{
G. Gunkel ${ }^{1}$, F. Selge ${ }^{1}$ \& M. do Carmo Sobral ${ }^{2}$ \\ ${ }^{1}$ Berlin University of Technology, \\ Chair of Water Quality Control, Germany \\ ${ }^{2}$ Universidade Federal de Pernambuco (UFPE), \\ Departamento de Engenharia Civil, Brazil
}

\begin{abstract}
The process of eutrophication has been recognized as a central problem in tropical reservoir environmental quality and sustainability, and some effects such as the mass development of macrophytes or algae, the occurrence of undesired species (e.g. cyanobacteria) and the emissions of methane as a greenhouse gas have been registered. Re-oligotrophication must be integrated into any reservoir and river basin management to minimize the environmental impact of dams. Up to now, only a little experience exists about eutrophication management of reservoirs, especially in the tropical zone, and nutrient cycling processes such as export from the watershed, remobilisation from the sediments and turn-over in the food web must be a focus of interest. Investigations were carried out in the semi-arid region of northeastern Brazil in the Itaparica reservoir, located in the São Francisco River, one of the largest rivers of South America. The potential for re-oligotrophication is evaluated in relation to the main contamination pathways such as export from the watershed (caatinga biome), land use in the watershed (irrigation agriculture), aquaculture in the reservoir, inflow by the São Francisco River, mineralization of inundated soils and vegetation, and leaching of the periodically desiccated littoral sediments. The critical export rate from the watershed is a useful tool to evaluate this contamination pathway. Concerning aquaculture, carrying capacity limits have been developed.
\end{abstract}

Keywords: re-oligotrophication, water reservoirs, dams, semi-arid, São Francisco, Itaparica. 


\section{Introduction}

Water reservoirs in tropical and semitropical areas have been the focus of conflicting discussions about environmental policy, natural protection and ecological functions for the last decade $[1,2]$. Without doubt water reservoirs are of high importance due to the human demand of freshwater for watering livestock and agriculture, and, also, for hydropower, because in many countries the availability of fossil energy resources is insufficient. Additionally water reservoirs promise economic development of the region by agriculture, aquaculture, boating and tourism. Thus in many countries priority of environmental policy is given to the construction of new dams, and indeed about 1000 large reservoirs are constructed every year [3]. The discussion of water reservoirs impact has become more intensive, on the one hand relating to the relocation of people, loss of nature and cultural goods, as well as socio-economic problems, and on the other hand by impact on nature due to eutrophication of the water body, emission of greenhouse gases and loss of ecosystem services [4]. Additionally, the production of irrigation agriculture in the tropics is evaluate by virtual water export [5], hydropower is not longer accepted as green energy [6], and fish aquaculture is seen as intensive mass fish farming with damage to the lake ecosystem [7].

Nowadays knowledge of tropical aquatic ecosystems with its biodiversity and ecological processes is still insufficient, especially in the semiarid and arid areas, because most investigations have been carried out in rainforests such as the Amazon and large wetlands such as Pantanal. This lack of knowledge leads to severe deficits in environmental assessment and prognostic evaluation of new planned dams for water storage.

One successful approach in dam lake ecosystem analysis has been the evaluation of existing reservoirs with an age of a few decades [8]. Quantification of the dynamics of ecological processes, mainly nutrient accumulation, evaluation of the new dam lake biocenosis and analyses of eutrophication processes will give a basis for development of knowledge-based models for planning of new reservoirs as well as to implement better and sustainable use of ecosystem services of for reservoirs.

Investigations of tropical water reservoirs point out that the most important process of a new dammed river is the eutrophication as a natural trophic upsurge process, followed by a cultural eutrophication [9]. Eutrophic reservoirs lead to many problems such as mass development of algae and macrophytes, occurrence of undesired species, impact on turbines by iron precipitation, and methane emission as greenhouse gas [6,9]. Thus the re-oligotrophication is a new approach, first to develop a better and sustainable management of existing water reservoirs, and second to point out and quantify ecological processes for the evaluation of new planned dams [10]. Re-oligotrophication has been successful applied to lakes all over the world, even large lakes, since about 1980, but experiences with dam lakes are very scarce and only a little research has been done about water reservoirs in the temperate zone. 
Our work focuses on the tropical and semitropical water reservoirs in Brazil, because of their model character for many other regions suffering under water stress and climate change effects such as the Mediterranean region and the Iberian Peninsula [10-12].

\section{Methods}

São Francisco River is one of the main rivers in Brazil, its water basin is $640,000 \mathrm{~km}^{3}$, stretching from Minas Gerais, the rainy southwest of Brazil, to the dry zone of North-eastern Brazil and has a length of 3,160 km. Up to the present, 8 reservoirs have been constructed, Itaparica among others being in the middle course of the river, located in the semi-arid region in the states Bahia and Pernambuco, $290 \mathrm{~km}$ from the Atlantic Ocean. Itaparica dam, finished in 1988, was build for hydroelectric power generation (1,479 MW), serving for water storage, too. Itaparica reservoir has a regulated inflow of $2,060 \mathrm{~m}^{3} / \mathrm{sec}$, a length of $149 \mathrm{~km}, 828 \mathrm{~km}^{2}$ surface and a sub water basin of 93,040 km². The maximum depth amounts $101 \mathrm{~m}$ (mean depth $=18 \mathrm{~m}$ ), the reservoir's capacity is $10.7 \times 10^{9} \mathrm{~m}^{3}$.

After 20 years of operation a comparative evaluation between environmental impacts foreseen in the environmental study and the situation nowadays is given [13-15]. For nearly 40,000 relocated people, a new economic base with irrigation agriculture had to be developed. Main water abstraction is for irrigation, representing $50.5 \%$ of the usage, but other uses are of increasing significance such as abstraction of water for aquaculture (pond culture at the margins) and net cage culture in the reservoir as well as for water transposition to the Northeast of Brazil.

For the last ten years, regular monitoring of water quality has been done by CHESF (Companhia Hidrielectrico do São Francisco) and physical, chemical and biological data analysed every two months. Furthermore, limnological and socio-economical studies have been carried out [11]; since 2012, the intraspecific research program INNOVATE (Interplay among multiple uses of water reservoirs via inNOVative coupling of substance cycles in Aquatic and Terrestrial Ecosystems [12) is active using standard limnological methods for water, sediment, and plankton analyses. Occurrence of reservoirs were analysed using the geospatially referenced GRanD data base [16].

\section{Results and discussion}

\subsection{Water reservoirs and their ecosystem service}

Damming up of rivers for flood control or water storage is a basic element of any river basin management, and due to the increasing significance of non fossil energy sources, a boom in dam construction has occurred all over the world, in total more than 48,000 large dams exist (> $15 \mathrm{~m}$ high), the most being in China (> 22,000; GRanD data base (fig. 1)). 
From the global point of view it is very important to state that nowadays most water reservoirs (75\%) are located in the tropical and subtropical zone $\left(>40^{\circ}\right)$. Dam lakes in the tropics are characterized by high insulation, all year primary production, high productivity, low oxygen concentration due to high water temperatures, intensive microbial processes such as nitrification and denitrification, and occurrence of undesired species (cyanobacteria, snail Biomphalaria as host of Schistosoma); impact on nature is more significant in tropical than in cold or temperate dam lakes. In general tropical dam lakes have a very high tendency to eutrophication.

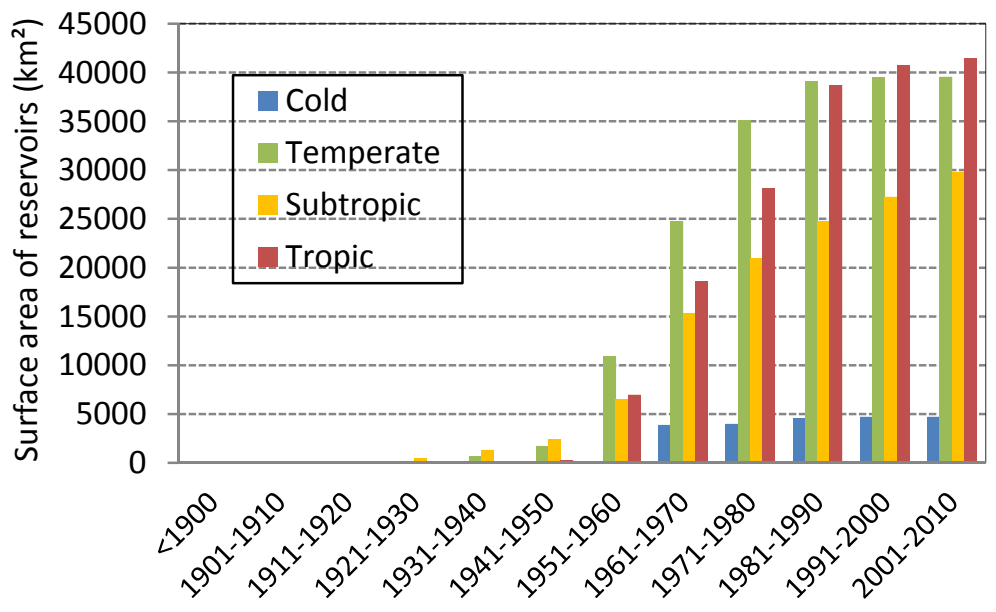

Figure 1: Development of large dams (> $15 \mathrm{~m}$ high), source: GRanD data base [16].

The concept of evaluation and protection of ecosystem services, also under consideration of economic valuation, is a useful tool to solve conflicts of multiple uses of water reservoirs; main ecosystem services are given by

- fresh water use for drinking water, watering, irrigation and aquaculture flow through systems,

- water purification by carbon metabolisation, denitrification and sedimentation,

- food production (commercial and substantial fishery), aquaculture and irrigation agriculture,

- hydropower energy production,

- $\quad$ water flow regulation (flood prevention),

- soil amendment by inundation of floodplains and by deposition of suspended sediments,

- sediment deposition within the reservoir and use of these sediments for soil amendment or construction (sediment management),

- local climate regulation (cooling, moisture),

- aesthetic value and recreation. 
These ecosystem services imply a sufficient water quality, in general an oligotrophic to mesotrophic state, and severe effects occur if water quality is insufficient (Table 1).

Table 1: Ecosystem services of tropical water reservoirs and requirements on water quality.

\begin{tabular}{|l|l|l|}
\hline $\begin{array}{l}\text { Ecosystem } \\
\text { service }\end{array}$ & $\begin{array}{l}\text { Minimum } \\
\text { water quality }\end{array}$ & Effects of insufficient water quality \\
\hline Drinking water & oligotrophic & $\begin{array}{l}\text { toxic effects of cyanotoxins, } \\
\text { accumulation of cyanotoxins, } \\
\text { disease by microbes (E. coli) and parasites } \\
\text { (Giardia, Cryptosporidium) }\end{array}$ \\
\hline Watering & mesotrophic & $\begin{array}{l}\text { toxic effects of cyanotoxins, } \\
\text { accumulation of cyanotoxins in cattle }\end{array}$ \\
\hline Irrigation water & mesotrophic & $\begin{array}{l}\text { accumulation of cyanotoxins in plants, } \\
\text { contamination of plants by microbes (E. coli) } \\
\text { and parasites (Giardia, Cryptosporidium) }\end{array}$ \\
\hline Aquaculture \\
water supply & oligotrophic & $\begin{array}{l}\text { accumulation of cyanotoxins in fish, } \\
\text { fish damage by low oxygen concentration }\end{array}$ \\
\hline Fishery & mesotrophic & $\begin{array}{l}\text { accumulation of cyanotoxins in fish, } \\
\text { loss of natural species, } \\
\text { fish infection by Tremadoda Clonorchis sinensis }\end{array}$ \\
\hline Biodiversity & mesotrophic & $\begin{array}{l}\text { loss of oligotrophic species, } \\
\text { occurrence of ubiquity and eutrophic species }\end{array}$ \\
\hline Hydropower & mesotrophic & $\begin{array}{l}\text { mechanical impact by macrophytes (Egeria } \\
\text { densa), iron precipitation in turbines }\end{array}$ \\
\hline Sediment use & mesotrophic & $\begin{array}{l}\text { anaerobic sediments, } \\
\text { toxic effects of sulphide ion }\end{array}$ \\
\hline Recreation & mesotrophic & $\begin{array}{l}\text { unaesthetic water body, } \\
\text { toxic effects of cyanotoxins to humans, } \\
\text { occurrence of water born diseases (Giardia, } \\
\text { Cryptosporidium, Schistosomiasis) }\end{array}$ \\
\hline
\end{tabular}

\subsection{Eutrophication processes of tropical reservoirs}

Eutrophication of lakes and to a lesser extent of rivers have been studied for many decades, and knowledge of biological processes and effects is substantial [17], but concerning water reservoirs knowledge is still scarce. Water reservoirs act as a reactor with input of nutrients from the watershed, high mobilisation rates of nutrients at the margins, internal input from lake inundated soils and vegetation, and primary production in form of floating or submerged macrophytes and of suspended algae.

A reservoir's carbon, respectively nutrient, cycle differs to that of natural lakes: 
(1) Often reservoirs have a dendritic form with large shallow areas and an elongated shore line, overall with intensive vertical water-mixing processes and nutrient recycling, that means a high proportion of more productive shallow lake areas leading to a high eutrophication potential [18];

(2) Many reservoirs have large littoral zones that are desiccated periodically by operational water level changes with high $\mathrm{N}$ and $\mathrm{P}$ release [19];

(3) Water reservoirs underlie a 'natural' rapid eutrophication process - the trophic upsurge $[8,9]$. This trophic upsurge is a general effect of damming up a river and is based on different ecological processes, (a) mineralisation of inundated vegetation and soils with a long-term release of nutrients, (b) changed hydrodynamic conditions with an increase of the potamon character of the water reservoir, meaning nearly stagnant water with increased temperature, reduced physical re-aeration, and settlement of suspended matter, (c) accumulation of fine sediments with a significant proportion of organic material; deficits of oxygen must be expected and can cause redox chemical re-mobilization of phosphorus, and (d) a long-term change in land use at the watershed of a reservoir due to migration of people to the reservoir margins, because economic possibilities are improved by tourism, fishery, fish production, and irrigated agriculture.

One effect of a high trophic level in water reservoirs is increased primary production with mass development of submerged (Egeria densa) or floating macrophytes (Eichhornia spp., Pistia stratoites) or of planktonic algae, with among others harmful cyanobacteria (e.g. Microcystis spp.). The tropical climatic conditions with all year high temperature and insulation promote mass development of a few algae species and they seem to reach an equilibrium state more frequently than in temperate water reservoirs that means long-term dominance of a few species with high biomass.

Eutrophic tropical water reservoirs have a high potential for methane emission as greenhouse gas due to the accumulation of organic rich sediments with anoxic conditions (figure 2); in eutrophic lakes $\mathrm{CO}_{2}$ is reduce to methane which has a 7.6 fold higher greenhouse effect, calculated per mol C. An analysis of available data points out the significance of shallow $(<20 \mathrm{~m})$ reservoir areas for direct ebullition. The quantity of methane emission strongly depends on water stratification processes in the reservoir and depth of turbine suction position because direct emission at turbines and the spillway occur, where deep water of the reservoir is pressure relieved [9, 20, 21].

\subsection{Re-oligotrophication potential}

Re-oligotrophication of water reservoirs is a new approach for reservoir management as a bundling of technical and management measures, which includes sanitation and restoration strategies. But, without doubt, intensity of land use in the watershed as well as of water body uses has to be restricted. Any limitation of anthropogenic water usage is based on analysis of the reservoirs eutrophication processes, especially the natural succession of the new man-made 


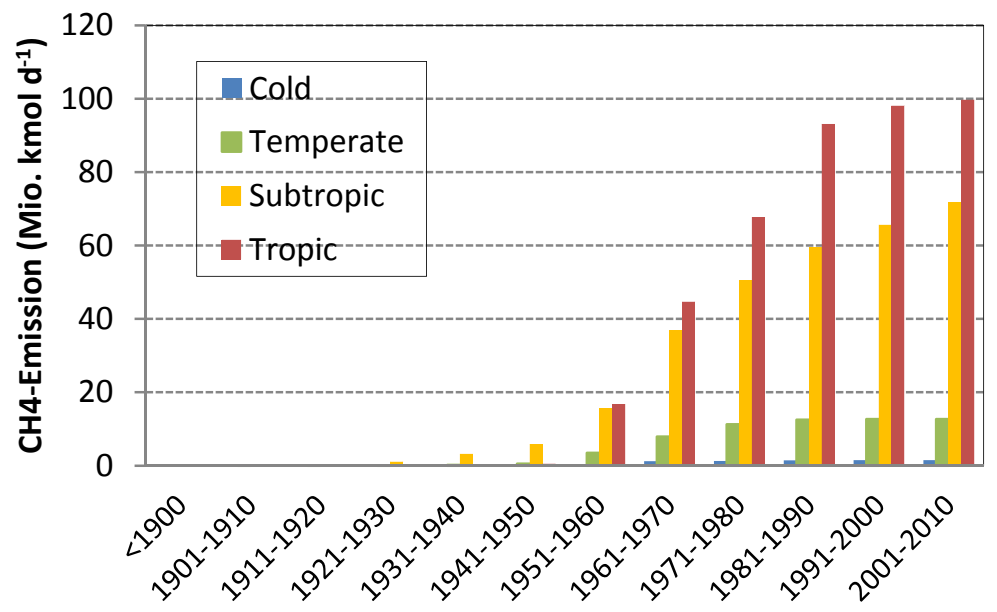

Figure 2: Calculated mean methane emissions of reservoir separated by climate zones and classified in decades since 1900 until 2010, data of Louis et al. [22] and Gunkel [9].

ecosystem to a eutrophic dam lake. Re-oligotrophication has been applied successfully in management of eutrophic lakes by restoration and sanitation measures [23, 24], but the experiences with dam lakes are very scarce. First results point out that some lake restoration technologies cannot be applied for dam lakes because of the difference between temperate and tropical ecosystems $[25,26]$.

\subsubsection{Critical export rates from the watershed}

Sanitation means pollution control in the watershed, and a critical export rate $\left(\mathrm{ER}_{\text {crit }}\right)$ in $\mathrm{kg} \cdot \mathrm{ha}^{-1} \cdot \mathrm{y}^{-1}$ [27] can be calculated on the basis of the critical $\mathrm{P}$ concentration in a water reservoir $\left(\mathrm{P}_{\text {crit }}\right), \mathrm{P}_{\text {crit }}$ is given by the plankton biomass, that means by the phosphorus use efficiency, being a lake specific correlation [10].

Vollenweider [28] calculated the critical P load as $\mathrm{g} \mathrm{m}^{-2} \mathrm{a}^{-1}$ on the basis of

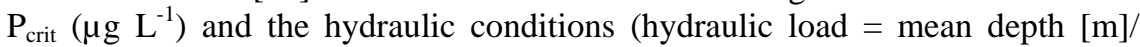
theoretical water residence time [a].

The critical export rate from watershed is given by Equation 1:

$$
\mathrm{ER}_{\text {crit }}=\mathrm{L}_{\text {crit }} \cdot \mathrm{A} \cdot 10-\left(\mathrm{P}_{\text {load }}-\mathrm{ER}\right)\left[\mathrm{kg} \cdot \mathrm{ha}^{-1} \cdot \mathrm{a}^{-1}\right]
$$

$\mathrm{ER}_{\text {crit }}=$ critical export rate from the watershed in $\mathrm{kg} \mathrm{ha}^{-1} \mathrm{a}^{-1}, \mathrm{~L}_{\text {crit }}=$ critical $\mathrm{P}$ load in $\mathrm{g} \mathrm{m}^{-2} \mathrm{a}^{-1}$, calculated by [28] eutrophication model, $\mathrm{A}=$ surrounding factor (lake surface/watershed), $\mathrm{P}_{\text {load }}=\mathrm{P}$ input into the reservoir in $\mathrm{g} \mathrm{m}^{-2} \mathrm{a}^{-1}$, $\mathrm{ER}=$ export rate from the watershed $\left(\mathrm{g} \mathrm{m}^{-2} \mathrm{a}^{-1}\right)$.

The critical export rate limits the overcharge of a water reservoir. For the Itaparica reservoir the actual ER is given by $10 \mathrm{~kg} \mathrm{~km}^{-2} \mathrm{a}^{-1} \mathrm{P}$. The $\mathrm{ER}_{\text {crit }}$ amounts only $7.1 \mathrm{~kg} \mathrm{~km}^{-2} \mathrm{a}^{-1} \mathrm{P}$ (without intensive aquaculture) and will decrease to 
$4.3 \mathrm{~kg} \mathrm{~km}^{-2} \mathrm{a}^{-1} \mathrm{P}$ with the planned intensive aquaculture (Table 2). The effect of the insufficient sewage treatment is low, but most $\mathrm{P}$ export is given by wash out and erosion in the watershed with natural caatinga, and the relative significance of the watershed area expressed by the surrounding factor of 112 . Activities are needed to reduce this pathway, e.g. by already established technologies such as water infiltration, rainwater harvesting, erosion control and vegetation strips along rivulets and reservoir margins [10, 29].

Table 2: $\quad$ Calculation of P loading of Itaparica reservoir (mod. from [10]).

\begin{tabular}{|l|l|l|c|}
\hline P source & Calculation base & P flux & $\begin{array}{c}\text { Reservoirs } \\
\text { P-load } \\
\mathbf{g ~ m}^{-2} \mathbf{a}^{-1}\end{array}$ \\
\hline $\begin{array}{l}\text { Natural P load } \\
\text { Inflow São Francisco }\end{array}$ & $2,154 \mathrm{~m}^{3} \mathrm{sec}^{-1}$ & P in water: $19.6 \mu \mathrm{g} \mathrm{l}^{-1}$ & 0.14 \\
\hline $\begin{array}{l}\text { Mineralization of inun- } \\
\text { dated soils }\end{array}$ & No information available & & - \\
\hline $\begin{array}{l}\text { Atmospheric deposition by } \\
\text { rain to the lake surface }\end{array}$ & $1.1 \mathrm{~kg}^{-1} \mathrm{a}^{-1}$ & & 0.001 \\
\hline $\begin{array}{l}\text { Internal load from } \\
\text { deposited sediments }\end{array}$ & No information available & & - \\
\hline $\begin{array}{l}\text { Anthropogenic caused } \\
\text { P load } \\
\begin{array}{l}\text { Mineralization of } \\
\text { inundated vegetation }\end{array}\end{array}$ & Biomass $=74 \mathrm{t} \mathrm{ha}^{-1}$ & P release $\approx 40 \mathrm{~kg} \mathrm{ha}^{-1}$ & 0.2 \\
\hline $\begin{array}{l}\text { Agriculture } \\
(70 \% \text { irrigation area) }\end{array}$ & 6,700 ha & P release $\approx 100 \mathrm{~kg} \mathrm{~km}^{-2} \mathrm{a}^{-1}$ & 0.01 \\
\hline Sub-basin (caatinga) & $93.000 \mathrm{~km}^{2}$ & P release $\approx 10 \mathrm{~kg} \mathrm{~km}^{-2} \mathrm{a}^{-1}$ & 1.12 \\
\hline Rural communities & 50,000 inhabitants & P release $\approx 1.5 \mathrm{~g} \mathrm{inh}^{-1} \mathrm{~d}^{-1}$ & 0.03 \\
\hline Actual aquaculture & Production: $4.000 \mathrm{t} \mathrm{a}^{-1}$ & P release: $52 \mathrm{t} \mathrm{a}^{-1}$ & 0.06 \\
\hline Planned aquaculture & Production $20,000 \mathrm{t} \mathrm{a}^{-1}$ & P release: $260 \mathrm{t} \mathrm{a}^{-1}$ & 0.32 \\
\hline
\end{tabular}

\subsubsection{Carrying capacity limits for fish aquaculture}

Fish aquaculture is regarded as an opportunity to improve the economic situation of people affected by dam construction, but the implementation of aquaculture techniques such as net cages in the lake or tanks and ponds at margins lead to severe nutrient input into the reservoir. In São Francisco water reservoirs, Tilapia (Oreochromis niloticus) is cultivated mainly in net cages; each one contains a fish biomass of about $1,000 \mathrm{~kg}$. The production cycle is only 6 months. Based on a food conversion factor of 1.3 and a production of 130 tons of fish, 170 tons of food are used yearly. This leads to an estimated annual input of $0.6 \mathrm{t} \mathrm{P}, 6 \mathrm{t} \mathrm{N}$ and $17 \mathrm{t}$ organic materials (food rests, faeces, [15]).

Determination of the carrying capacity of a reservoir respectively of distinct reservoir branches is an auspicious new approach in reservoir management, a key factor, that will allow limited aquaculture; different parameters can be used to calculate carrying limits, such as oxygen balance of the water, phytoplankton and macrophytes biomass as well as sediment composition with organic matter accumulation beneath the net cages [30]. In the case of Itaparica reservoir, the 
critical load of the reservoir $\left(1.2 \mathrm{~g} \mathrm{~m}^{-2} \mathrm{a}^{-1}\right)$ does not permit an additional $\mathrm{P}$ load of $0.32 \mathrm{~g} \mathrm{~m}^{-2} \mathrm{a}^{-1}$ from fish aquaculture (table 2).

\subsubsection{Desiccation of the littoral zone}

Regular operational level of the São Francisco Reservoir varies by about $5 \mathrm{~m}$, and periodically large littoral areas become dry due to the extended shallow lake areas (Fig. 3). In total $27 \%$ of the dam lake water surface become dry when the operational water level decreases by $5 \mathrm{~m}$ to minimum level. During desiccation periods sediments are mineralized, leading to high nutrient export into the reservoir. Littoral fauna and flora are impeded and the ecological value of the littoral zone is extremely reduced. These dried littoral zones are also used for cattle farming and agriculture, and they release nutrients and agrochemicals with increasing water level. Only a few pioneer organisms develop during inundation periods such as the macrophytes Egeria densa or molluscs, thus aquatic biodiversity is extremely reduced.

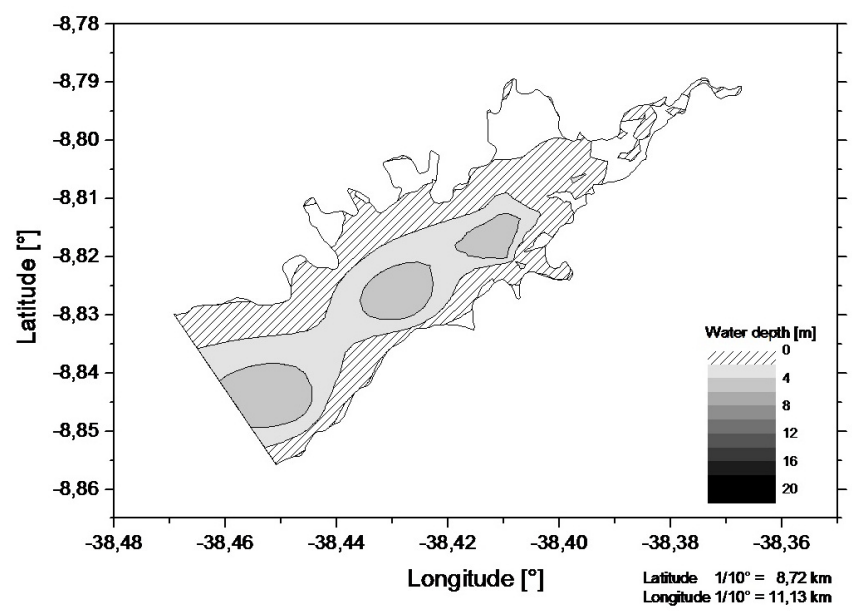

Figure 3: Bathymetry of the Ico-Mandantes bay with desiccated (white) and shallow (lined) areas.

Annual seasonal water level fluctuation of Itaparica reservoir, caused by operational conditions of the hydropower station, amounts up to $5 \mathrm{~m}$. This leads to a significant promotion of eutrophication of the dam lake. Main effects of the desiccation of littoral zones are

- increment of suspended material in the water column resulting from water turbulence by wind induced waves,

- disruption or impairment of thermal lake stratification,

- break down of submerged littoral macrophytes and release of nutrients,

- aerobic mineralisation of organic matter of desiccated sediments,

- change of exfiltration conditions during high water level to infiltration conditions during low water level. 
Additionally, the smaller water body volume leads to a reduced dilution of nutrient input, meaning increasing concentrations.

Ecologically optimized hydropower plant management has to limit regular water level changes in the reservoir to low extent and to short periods; this prevents the use of these areas for temporarily agriculture, too. Of course, a short term decrease in the water level needs to be made for flood control, but energy generation has to be limited to available water, that means the inflow rate. This conflicting aspect becomes more intensive by increasing scarcity of available water due to climate change effects.

Ecologically orientated dam management can support the reservoir water quality by flushing out floating algae using the epilimnic outlet to the turbines as well as by deep water discharge for nutrient export by using the hypolimnic outlet. This aspect - altitude of the turbine water inlet - has great significance for methane emissions, too, because an accumulation of methane generally occurs only in the hypolimnic water body [9].

\subsubsection{Reuse of sediments}

The abstraction and reuse of deposited sediments is regarded as a useful tool for water reservoir management, because (1) the useable water volume of the reservoir will be maintained, (2) the abstraction of reservoir sediments leads to an output of nutrients, mainly phosphorus and organic matter, and will reduce the eutrophication process, and (3) the reuse of the sediment in agriculture will enhance soil quality, additionally more coarse sediments can be used in construction.

Concerning re-oligotrophication, sediment abstraction will stabilize any thermal stratification, and by removal of organic rich sediments, the oxygen concentration of the overlying water will increase and the probability of redox chemical phosphorus mobilization will decrease. Up to the present only few a studies had been carried out to analyse the potential of this sediment management [31, 32].

Sediment reuse is promoted by sediment sorting within reservoirs due to inflow current and wind wave action with resuspension of littoral sediments, coarse and fine sediments being deposited at different places. Additionally, sediment traps can be used near a tributary for accumulation and abstraction of eroded soils from the watershed.

\section{Conclusion}

Re-oligotrophication is a new concept in water research management, but notwithstanding the success reached in natural lake re-oligotrophication, mainly in the northern hemisphere, much research has to be done to adopt and apply these technologies to tropical reservoirs. Many ecological processes of tropical reservoirs differ to those of temperate dam lakes.

Successful strategies in re-oligotrophication of tropical water reservoirs are the application of the critical export rate to minimise the export from the watershed by land use and run off using reforestation, rain water storage and 
vegetation strips along rivulets. Another approach must be the changed hydropower operation conditions with focus on the ecosystem, which means dramatic water level changes with desiccation of large littoral areas must be avoided. Aquaculture systems lead to a severe eutrophication of a water body, and restrictive regulation is necessary to limit this process, carrying capacities will give ecosystem-specific data for planning and evaluation of this activity. Additionally, sediment management with abstraction of sediments and use in agriculture or construction is very useful to promote a more oligotrophic state as well as to avoid sediment accumulation within the reservoir and a decrease in the useable water volume.

The re-oligotrophication concept and its application to Itaparica reservoir will give an example of advanced reservoir management and a sustainable use of ecosystem services.

\section{Acknowledgements}

This study is part of the German-Brazilian research program INNOVATE (Interplay among multiple uses of water reservoirs via innovative coupling of substance cycles in Aquatic and Terrestrial Ecosystems) with the support of the Federal Ministry of Education and Research (BMBF). The authors would also like to thank Mr R. Hatton for his lingual revision of this paper.

\section{References}

[1] Biswas, A.K., Dams: Cornucopia or Disaster? Water Resources Development, 20(1), 3-14, 2004.

[2] Tundisi, J.G., Matsumura-Tundisi, T. and Tundisi, J.E.M., Reservoirs and human well being: New challenges for evaluating impacts and benefits in the neotropics. Braz. J. Biol., 68, 1133-1135, 2008.

[3] WRD (2013) World Register of Dams. Online. http://www.icoldcigb.org/home.asp [10] Gunkel, G. and M. Sobral, M.C., Reoligotrophication as a challenge for tropical reservoir management with reference to Itaparica reservoir, São Francisco, Brazil. Water Sciences and Technology, 67(4), 708-714, 2013.

[4] WCD, Dams and Development - A new framework for decision-making. World Commission on Dams, Earthscan Publications, London, UK, 322 pp., 2000.

[5] Siebert, S. and Döll, P., Quantifying blue and green virtual water contents in global crop production as well as potential production losses without irrigation. J. of Hydrology, 384, 198-217, 2010.

[6] Giles, J., Methane quashes green credentials of hydropower. Nature, 444, 524-525, 2006.

[7] Lehmusluoto, P. and Tarcyznska, M., Workshop on Lake Management and Eutrophication Control for Donghu Lake. Newsletter and Technical Publication, Freshwater Management Series No. 8, App. 5, Technical Report. UNEP IETC Publ., 2002. 
[8] Gunkel, G., Lange, U., Walde, D. and Rosa, J.W.C., Environmental and operation impacts of Curuá-Una, a reservoir in the Amazon region of Pará/Brazil. Lakes and Reservoirs: Research and Management, 8, 202-216, 2003.

[9] Gunkel, G., Hydropower - A green energy? Tropical reservoirs and greenhouse gas emissions. Clean, 37, 726-734, 2009.

[10] Gunkel, G. and M. Sobral, M.C., Re-oligotrophication as a challenge for tropical reservoir management with reference to Itaparica reservoir, São Francisco, Brazil. Water Sciences and Technology, 67(4), 708-714, 2013.

[11] Gunkel, G. and Sobral, M.C., Reservoirs and River Basins Management: Exchange of Experience from Brazil, Portugal and Germany. Universitätsverlag der TU Berlin, ISBN: 978-3-7983-2056-7, 279 pp., 2007.

[12] INNOVATE (2012). Interplay among multiple uses of water reservoirs via innovative coupling of substance cycles in aquatic and terrestrial ecosystems. Online. http://www.innovate.tu-berlin.de/v-menue/startseite/

[13] Sobral, M.C., Ist die Unweltverträglichkeitsprüfung ein wirksames Instrument des Unweltschutzes in Brasilien? Ph.D thesis. Institute of Environmental Planning, Technical University of Berlin, Germany, 1991.

[14] Sobral, M.C., Carvalho, R.C.O. and Figueiredo, R.C., Management of environmental risks from multipurpose use of reservoirs in semiarid areas of São Francisco River, Reservoirs and River Basins Management: Exchange of Experience from Brazil, Portugal and Germany, eds. G. Gunkel and M.C. Sobral, Universitätsverlag der TU Berlin, 14-26, 2007.

[15] Gunkel, G., Contamination and eutrophication risks of a reservoir in the semi-arid zone: Reservoir Itaparica, Pernambuco, Brazil, Reservoirs and River Basins Management: Exchange of Experience from Brazil, Portugal and Germany, eds. G. Gunkel and M.C. Sobral, Universitätsverlag der TU Berlin. 81-95, 2007.

[16] Lehner B., Reidy Liermann C., Revenga C., Vörösmarty C., Fekete B., Crouzet P., Döll P., Endejan M., Frenken K., Magome J., Nilsson C., Robertson J.C., Rodel R., Sindorf N., and Wisser D., Global Reservoir and Dam Database, Version 1 (GRanDv1): Dams, Revision 01. Palisades, NY: NASA Socioeconomic Data and Applications Centre (SEDAC). Online. http://sedac.ciesin.columbia.edu/data/set/grand-v1-dams-rev01

[17] Conley, D.J., Paerl, H.W., Howarth, R.W., Boesch, D.F., Seitzinger, A.P., Havens, K.E., Lancelot, C. and Likens, G.E., Controlling eutrophication: Nitrogen and Phosphorus. Science, 323, 1014-1015, 2009.

[18] Havens, K.E. and Schelske, C.L., The importance of biological processes when setting total maximum daily loads (TMDL) for phosphorus in shallow lakes and reservoirs. Environmental Pollution, 113, 1-9, 2001.

[19] Mitchell, A.M. and Baldwin, D.S., The effects of sediment desiccation on the potential for nitrification, denitrification, and methanogenesis in an Australian reservoir. Hydrobiologia, 392, 3-11, 1999. 
[20] Fearnside, P.M., Do hydroelectric dams mitigate global warming? The case of Brazil's Curuá-Una dam. Mitigation and Adaptation Strategies for Global Change, 10, 675-691, 2005.

[21] Guérin, F., Abril, G., Richard, S., Burban, B., Reynouard, C., Seyler, P. and Delmas, R., Methane and carbon dioxide emissions from tropical reservoirs: Significance of downstream rivers. Geophysical research Letters, 33, dio: 10.1029/2006GL027929, 2006.

[22] Louis, V.L.S., Kelly, C.A., Duchemin, É., Rudd, J.W.. M. and Rosenberg, D.M., Reservoir surface as sources of greenhouse gases to atmosphere: A global estimate. BioScience, 50(9), 766-775, 2000.

[23] Anderson, N.J., Jeppesen, E., and Søndergaard, M., Ecological effects of reduced nutrient loading (oligotrophication) on lakes: an introduction. Freshwater Biol., 50 (10), 1589-1593, 2005.

[24] Mehner, T., Diekmann, M., Gonsiorczyk, T., Kasprzak, P., Koschel, R., Krienitz, L., Rumpf, M., Schulz, M. and Wauer, G., Rapid recovery from eutrophication of a stratified lake by disruption of internal nutrient load. Ecosystems, 11, 1142-1156, 2008.

[25] Jeppesen, E., Søndergaard, M., Mazzeo, N, Mariana Meerhoff, M, Christina C. Branco, C.C., Huszar, V. and Scasso, F., Lake restoration and biomanipulation in temperate lakes: Relevance for subtropical and tropical lakes, Restoration and Management of Tropical Eutrophic Lakes, ed. M.V. Reddy, Oxford \& IBH Publishing, New Delhi, 331-349, 2005.

[26] Huszar, V.L.M., Caraco, N.F., Roland, F. and Cole, J., Nutrient-chlorophyll relationships in tropical-subtropical lakes: Do temperate models fit? Biogeochemistry, 79, 239-250, 2006.

[27] Wolfram, G., Argrillier, C., Bortoli, J. de, Buzzi, F., Dalmiglio, A., Dokulil, M. T., Hoehn, E., Marchetto, A., Martinez, P.-J., Morabito, G., Reichmann, M., Remec-Rekar, Š., Riedmüller, U., Rioury, C., Schaumberg, J. , Schulz, L. and Urbanič, G., Reference conditions and WFD compliant class boundaries for phytoplankton biomass and chlorophyll-a in Alpine lakes. Hydrobiologia, 633, 45-68, 2009.

[28] OECD, Eutrophication of waters - monitoring, assessment and control. Organisation for Economic Co-operation and Development. Paris, 154 pp., 1982.

[29] Carvalho, R.M.C, Sobral, M., Costa, M.R., Gunkel, G., Silva, M.M. and Lôbo, L., Subsurface Dams for Water Storage and Sustainable Development in Semi-arid Areas. Sustainable development: Energy, environment and natural disasters, eds. L.M.G. Duarte and P. Pinto, Fundação Luis de Molina, Lisboa. 149-158, 2009.

[30] Gunkel, G. Steemann, J. and Sobra, M.C. Carrying capacity limits in net cage fish production in water reservoirs, The INNOVATE Project: Sustainable Uses SES of Water Reservoir and Terrestrial Ecosystems in Semiarid of Brazil,eds. G. Gunkel, M.C. Sobral and J.A. Aleixo da Silva, Universitätsverlag der TU Berlin. In press, 2013.

[31] Theodoro, S.H., Fonseca , R.M., Barriga, F.J.A.S. and Macedo, I.L., The use of accumulated sediments in the Tucuruí and Três Marias dams to 
326 River Basin Management VII

recover degraded soils, Reservoirs and River Basins Management: Exchange of Experience from Brazil, Portugal and Germany eds. G. Gunkel and M.C. Sobral, Universitätsverlag der TU Berlin, 211-225, 2007.

[32] Walter, K., Gunkel, G. and Gamboa, N., An assessment of sediment reuse for sediment management of Gallito Ciego Reservoir, Peru. Lakes and Reservoirs: Research and Management, 17, 301-314, 2012. 